\title{
THE BLENDED LEARNING IMPLEMENTATION OF ELT BASED ON TEACHERS' AND STUDENTS' PERSPECTIVE IN NEW NORMAL CONDITION OF COVID 19
}

\author{
Lukman Arif Rachman ${ }^{1}$, Sudiyono ${ }^{2}$, Elzi Phonix ${ }^{3}$ \\ 1,2,3 IKIP Siliwangi \\ ${ }^{1}$ Lukmanarifrachman@gmail.com, ${ }^{2}$ sudiyonostkipslw@gmail.com, ${ }^{3}$ elziphonix@gmail.com
}

\begin{abstract}
This study aims to determine the perceptions of teachers and students towards the implementation of blended learning in English, at high schools in the city of Bandung. The research method adopted for this research is the mix method between qualitative and quantitative. Participants involved were teachers and students taken randomly from as many as nine senior high schools spread across the city of Bandung. The technique and data processing were carried out by distributing a questionnaire that each participant had to fill in, the questionnaire contained seven aspects of how they responded to the advantages each of both teachers and students due to the English blended learning method. After the data were collected, then an analysis was carried out by calculating on the perceptions of teachers and students. The main advantage according to the teachers perception was challenging for teachers in preparing the material and using the media (93\% perception responses). Meanwhile, the main advantage according to students perception was that English blended learning could improve their language skills (77\% perception responses). As suggestions, it can be conveyed that blended learning can be continued for this era of Covid 19.
\end{abstract}

Keywords: English, Blended Learning, Teachers' Perspective, Students' Perspective

\section{INTRODUCTION}

Since the pandemic of Covid 19 hit Indonesia, the implementation of teaching and learning process in the schools should be adapted with the regulation coming from the government. The main reason is because the regulation coming from the government force the school to limit the implementation of offline meeting and force the schools to implement online meeting. Otherwise, the implementation of online learning also bring up some problems which also make the schools should combine both online and offline meeting (Pardede, 2012). The combination of online and offline learning is also called as blended learning or hybrid learning. The implementation of blended learning has being a demand and also trend for teachers and students in Indonesia in order to facilitate the effective teaching and learning in new normal era of covid-19 pandemic. This trend forces the teachers to develop online media and material in the process of teaching and learning such as using some platform, social media and any other online sources. As the example in Bandung as the urban area in West Java Province, almost 164 senior high school in Bandung have been forced to implement technology in the process of teaching and learning in order to achieve Bandung as the smart city. Regarding to the new normal era of Covid-19 pandemic, almost all the schools in Bandung have no choice to implement blended learning as the way to facilitate the teachers and students in conducting teaching and learning process. Meanwhile, since Bandung as one of big city in West Java

Province, the teachers and students are easy to access internet and media technology. 
Considering to the implementation of blended learning in English teaching, the students can learn more contextually since the online media can support the students to learn of how the native use the language in the real life. Bielawska (2012) mentioned that the implementation of blended learning in English teaching and learning is the effort to facilitate the students learn effectively. Moreover, Bielawska (2012) also describes that the implementation of blended learning can improve the students score which indicate the improving students' vocabulary mastery. Additionally, blended learning is the teaching and learning approach which is recommended to be implemented in the new normal era. Syarif and Sofyan (2012) also state that English blended learning implementation can improve the students' understanding comparing to the implementation of online or face to face learning. The reason is because the lack aspects which can't be covered in online learning can be covered in face to face teaching and learning process (Pardede, 2012).

However, there are still some weaknesses in blended learning implementation in English teaching and learning which generate the negative effect. Otherwise, the investigation and publication about the effect of blended learning implementation are still limited especially in English teaching and learning regarding to the students and teachers perspective as those who implement directly the blended learning implementation. Therefore, this study was urgent to investigate the positive and negative effect of blended learning implementation in English teaching and learning base on students and teachers perspective. This study also can be the basis for school and teachers in the implementation of blended learning.

\section{Blended Learning in English Teaching and Learning}

The use of technology, information and communication technology (ICT), in education is really popular for the last three decades in Indonesia. The implementation of ICT in English teaching and learning can improve the quality of teaching and learning both face to face learning and online learning. It can be denied that the implementation of online media in English teaching and learning can improve the students' vocabulary mastery and create the flexibility to help students easier in understanding material (Shen, 2004). The reason is because the teaching and learning process can be facilitated with authentic and realistic media such as the use of video of how English native speaker use the language. Moreover, Riley (2000) also states that the use of online technology stimulates students to learn more effective and improve the students' learning achievement.

However, in the implementation of technology in English teaching and learning is still bringing up some weaknesses which can be the obstacles for teachers to facilitate the effective teaching and learning for students. Therefore, the combination of face to face and online learning is popular to use as a hybrid approach in many institution to cover the weaknesses from online or face to face teaching and learning. The Implementation of English blended learning in Indonesia nowadays has been popular since the teaching and learning process should be conducted through online learning. Unfortunately, since there are some lacks of teaching and learning through online, some schools especially in Bandung also force the teachers to conduct the combination of online and offline learning in English teaching.

Throne (2003) mention that the use of blended learning can be the learning style for the students nowadays to enrich the learning experience of the students since they can access the unlimited sources from internet with still having the guidance from teacher through face to face learning. In addition, blended learning is believed can make the students in English teaching and learning more involve actively in order to improve their language skills in the 
target language (Wang, et.al, 2009). Below is the illustration of blended learning implementation.

The illustration of blended learning implementation

The research about blended learning implementation in English teaching and learning have been conducting for a decade by some researchers (Adas \& Bakir, 2013; Akbarov, et.al, 2018; Ghazizadeh \& Fatemipour, 2017; Grgurovic, 2011; Liu, 2013; Manan, Alias, \& Pandian, 2012; Shih, 2012) while mostly the investigations were focused on the effectiveness of blended learning in English teaching and learning as a foreign language. According to the previous investigation conducted by Pardede (2012), mostly the teachers assumed that the students couldn't improve and explore their all language skills if the teaching and learning process were only focused through offline learning. Then, by combining the online learning, the students have more opportunities to improve their language skills. In line with Pardede (2012), Bijeikienè, Rašinskiene, Zutkiene's (2011) also mention in their research that the combination online and offline meeting can grow the positive motivation of the students in learning English as a foreign language.

Considering to many investigations of blended learning in English teaching and learning in Indonesia, the investigation of the impact blended learning implementation were still focused on the result and the achievement of the students considered to the students score. Therefore, this research focus on the impact of blended learning implementation based on teachers and students' perception as those who get the impact directly with the implementation of blended learning in English teaching and learning.

The Teachers' Perspective in English Teaching as Foreign Language in Indonesia Perspective can be defined as the way of person in seeing something which can be the foundation in thinking and perceiving something. Perception can be defined as the point of view toward something and as one of the philosophy meaning in which each person will have different meaning and subjectively on it (Hamid, 2012). Perception is also about what we understand or interpret from five senses - touch, sight, sense, smell, and taste. However, perception is colored by our past experiences, feelings, and thought. The same scene can be understood in two different ways by two different individuals. It can be exampled when two individuals are looking at the same picture would interpret it in two ways. One can say that the glass is half empty whereas another would say that it is half full. Thus, it is clear that different individuals can understand and interpret the same information in different ways.

Regarding to the perception of teaching and learning English as foreign language, Ryle' (1949) in Crookes (2009) mentions the value of learning foreign language means also learning knowledge, in this case learning of knowing how such as how to express something in the target language. Enabling students are able to communicate in the language is the core point in teaching English as foreign communication tool. Moreover, Crookes also says that in learning language, knowing a language is not only "know-how" but also know the knowledge that enables them to use the language effectively when communication within another culture. It means that since English is foreign language, knowing how to use the language should be melted with the culture of the speakers.

Musthafa in his lecturing (2015) also mentioned that teachers should have perception that in teaching English, the L1 of students should be established first since it will be the foundation 
of their L2. After students have already known how to use their L1, it will help students also to know how to use L2 based on their L1. Hence, this perception is in line with Gadamer' view in Crookes (2009) that transferring knowledge to students in learning language is not make students knowing what, or knowing that but also knowing how.

Regarding to the teachers' perception in teaching and learning, Gultom (2015) states that there are teachers' perceptions in viewing English teaching. Many teachers think that English teaching is same as science teaching while students should understand to the content of the language. Otherwise, other teachers view that English teaching should be more of teaching the language skills which means that it takes a long time to train the students to become fluent in using English.

Considering to the perception of English teachers in English teaching, Rachman (2015) has been conducted the investigation about the perception of English teachers to English teaching. Rachman (2015) investigates that most of English high school teachers in Bandung, West Java, argue that teaching English is the process to prepare students passing from the test and completing the material in the syllabus without seeing the students' need. Therefore, students are framed to see that English is the subject that should be learned cognitively. As the result, many students are demotivated to learn English. Otherwise, only some teachers believe that teaching and learning English for students is how to make students able to use English actively both in spoken and written language.

In this study, there are seven points about teachers' perception in English learning and teaching. The points can be seen in the Chart below.

Teachers' Perception in English Learning and Teaching

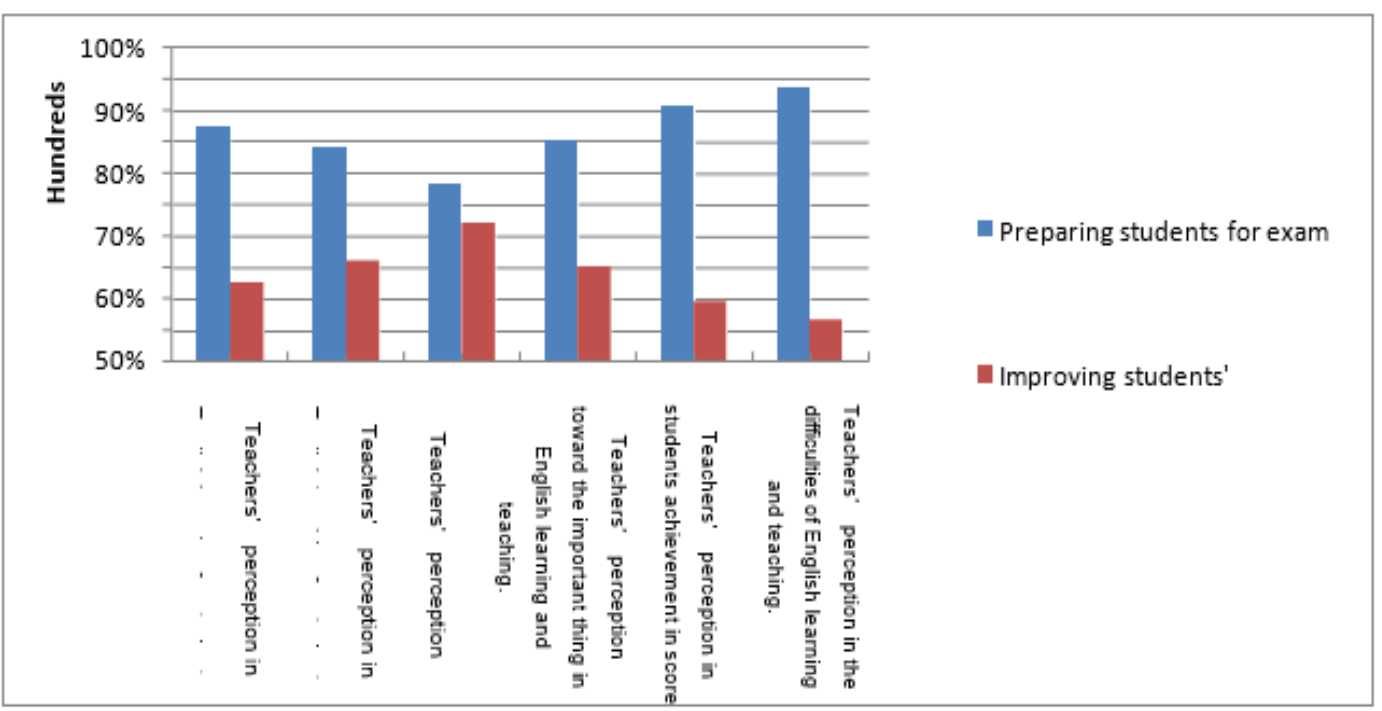

\section{The Students' Perspective in English Learning as Foreign Language in Indonesia}

English as a foreign language in Indonesia is always seen as the difficult language to be learned by the students in the schools. However, according to Rachman (2015) that even English is a foreign language to be used in Indonesia, mostly the students have the perspective that English the important subject to be learned since to graduate from school and university, the students is required to pass from English exam. In addition, the students also believe that nowadays, English as a lingua franca will be very helpful to support career and also socialize with other people from other countries. 
Otherwise, according to Rachman (2015) investigation, mostly the students can improve their English language skills from independent learning which can be from internet. It is because the students can learn English informally such us from video, article or song which they can access in internet. Moreover, based on Rachman (2015) that most of the students in urban area have perspective that learning English independently by using authentic media from internet can make them know more of how the language used naturally like in touch directly with English native speaker. The reason is because the English learning process conducted in the school are too somber and just focus on improving students ability in answering the question for exam than improving the students' language skills. It is also the impact while based on the teachers perspective in Indonesia, the English learning in high school level is only one hour and half which is not enough to cover the need of the students in improving their language skills and the requirement to pass from examination.

Considering to some perspective of the students in Indonesia in learning English, nowadays the teachers have been trying to mix both online and offline learning in teaching and learning process in order to cover the students' need to improve their language skills and the demand to pass from the examination.

\section{METHOD}

The mix method is used to investigate the focus of the study about the teachers and students perspective to the effect of English blended learning implementation. The mix method proposed by Malik \& Hamid (2014) is adapted in this study to combine the data collection and analysis quantitatively and qualitatively. Therefore, the likert scale questionnaire which collected and analyzed quantitatively will be combined with the use of interview which collected and analyzed qualitatively. The likert scale questionnaire can be used to collect the perspective of participant in huge population (Kendal (2008) in Harris \& Brown (2009)). The likert scale used in the study is psychometric response scale to measure agree or disagree based on the given statement in the questionnaire. In addition, the use of interview adapted from Rachman (2015), Lee (1997), Susikaran (2013), Selvarani dan Vadivio (2013), can validate the data obtained from questionnaire. The use of interview was also aimed to obtain further information which can be access by using questionnaire (Harris \& Brown, 2009).

One hundred and eighty students and 9 English teachers coming from three different schools in Bandung, West Java were involved as the participants to give their perspective to the English blended learning implementation. The three schools are chosen since they are the schools that have been actively implementing English blended learning for several years and even in the pandemic of Covid 19 condition. In addition, the schools are also actively implementing LMS, Learning Management System, which can facilitate teachers and students to implement blended learning during English teaching and learning.

In collecting the data, all students from three schools were asked to give their perspective through the questionnaire given by researcher. In addition, three students from each school were ask to also give their perspective through the interview given by researcher. To collect the data about teachers' perspective, nine teachers also were asked to give their perspective through the questionnaire and one teacher from each school were interviewed by researcher to get the data qualitatively. After the data has been collected, the next step is to calculate the percentage of students' perceptions who agree that blended learning has advantages, as well as the teacher's perceptions. From the results of calculations and data processing, it is known how many students and teachers stated that the learning method had advantages and vice versa. 


\section{RESULTS AND DISCUSSION}

\section{Results}

This part is divided into two parts, the first part discuss the teachers' perspective in English blended learning based on the data obtained from questionnaire and interview. The second part about the students' perspective in English blended learning implementation based on the data from questionnaire and interview.

\section{The Teachers' Perspective}

There are seven aspects focus on this study to investigate the teachers' perspective in English blended learning implementation. There are blended learning implementation to the students' motivation in learning, language skills, grammar comprehension, and students' autonomous learning. The other aspects are the challenge for the teachers in English blended learning implementation. The last aspect is the teachers' perspective that blended learning can cover the lack exist in online and offline learning. The table below is the data obtained from questionnaire about the teachers' perspective.

\begin{tabular}{|c|c|c|c|c|c|}
\hline No & Aspects & $\begin{array}{l}\text { Strongly } \\
\text { disagree }\end{array}$ & Disagree & Agree & $\begin{array}{l}\text { Strongly } \\
\text { Agree }\end{array}$ \\
\hline & $\begin{array}{l}\text { Increasing students' } \quad \text { motivationin } \\
\text { English learning. }\end{array}$ & 0 & 1 & 6 & 2 \\
\hline & Increasing students' language skills & 0 & 0 & 2 & 7 \\
\hline & $\begin{array}{ll}\text { Increasing } & \text { students' } \\
\text { comprehension } & \end{array}$ & 0 & 2 & 5 & 2 \\
\hline & $\begin{array}{l}\text { Triggering } \quad \text { students' } \\
\text { learning }\end{array}$ & 0 & 3 & 4 & 2 \\
\hline & $\begin{array}{l}\text { Challenging for teachers in preparing the } \\
\text { material and using the media }\end{array}$ & 0 & 0 & 0 & 9 \\
\hline & $\begin{array}{l}\text { Blended Learning help the teachers to cover the lack } \\
\text { exist in online and offline learning. }\end{array}$ & 0 & 0 & 0 & 9 \\
\hline & $\begin{array}{l}\text { Helping students to learn } \\
\text { contextually. }\end{array}$ & 0 & 0 & 0 & 9 \\
\hline
\end{tabular}

\section{*Note: The total of the teachers}

According to the data obtained from questionnaire, it can be seen that most of the teachers agree that the implementation of blended learning in ELT can increase students' motivation in learning. The teachers also say in the interview that the most of the students are involved actively in the learning process especially in online learning such as the group discussion in LMS, Learning Management System, and online students' work. Some students who used to passive in offline learning can be easily involve actively in online learning. The reason is because the implementation of blended learning can grow the students' positive attitudes which impact increasing students' motivation in learning process (Fakhir, 2015).

All teachers also agree that the implementation of blended learning in ELT can improve the students' language skills. It can be seen that in these three schools the students score achievement increase in online meeting comparing to offline meeting. The reason mentioned 
by the teachers in the interview that mostly the students are easier to use online learning since the students are classified. In addition, the online media provide unlimited materials that can be used by students to learn English as foreign language such as YouTube, media social, and website which can facilitate students to learn individually. It can't be denied that mostly the students also like to watch the English video and read some English news or articles which can improve students' language skills. The teachers also mention in the interview that the implementation of blended learning in ELT can facilitate more the students to not only learn English during offline learning process which is limited for teachers but also in online meeting to improve students' language skills.

The other statement also stated by the teachers that the reason of why English blended learning can improve the students' language skills is because the students can learn the language more contextually of how English used by English native speaker through the implementation blended learning. It is because in offline learning, the students can learn the content and the new vocabulary and expression discussed by the teachers while in online learning the students can know of how the vocabulary and expression used naturally by native speaker through the video they watch. All teachers also agree that English blended learning implementation can help the students to learn English more effectively since mostly the students prefer to learn from online media which are more fun for the students. As the result, the implementation of blended learning can triggers students autonomous in English learning (Al-Haq \& Al-Sobh, 2010). In the other words, blended learning suits the students' need in learning English through online meeting and the teaching goals which can be covered in offline meeting (Chansamrong, et.al., 2014).

Considering to the students' grammar comprehension, seven teachers agree that the implementation of blended learning can increase the students' grammar comprehension comparing to the score of the students obtained before and after the implementation of blended learning. The teachers stated in the interview that through the use of English learning Website such as British Council, BBC Learning English, and Duolingo can facilitate more the students to learn grammar individually. The interesting media such as pictures and videos provided in website also get the students easier to understand about English grammar. Isti'anah (2017) also support in her investigation that the effect of blended learning in ELT can increase the students' grammar achievement since in teaching and learning grammar, the teachers will be so difficult to explain grammar comparing to online meeting which provided with various media for students. However, the guidance from the teachers to help the students understand more about grammar is still needed to avoid miss understanding and confusion of students toward the grammar learned.

Even though English blended learning implementation give a lot positive effect in English blended learning, based on the data obtained from questionnaire, all teachers strongly agree that the implementation of blended learning is very challenging for the teachers. The reason is because the teachers should create more materials which are not only should be prepared for offline meeting but also in online meeting. In addition, the teachers also may found difficulties to find out the appropriate online material that can be match with the material discussed, the students' language level, and the target language that should be learned by the students.

Taking a look to the implementation of both online and offline meeting, the teachers believe that they always face some lacks both in online and offline. Therefore, from the questionnaire, all teachers agree that blended learning can help teachers to cover the lack exist both in online 
and offline learning. In online learning some materials will be difficult for the students to be learned because they still need direct guidance from teacher. Otherwise, some target learnings can be achieve if learning process is only conducted in offline meeting due to the offline limitation time. Therefore, through blended learning, the lack come up from online and offline meeting can be covered by the teachers.

\section{The Students' Perspective}

There are some aspects focused on this study as the students' perspective in English blended learning implementation. The aspects are English blended learning to the students' motivation, grammar skill, language skills, and students' comprehension in English learning. The table below is the data obtained from questionnaire about the students' perspective in English blended learning. The data obtained from questionnaire are displayed in percentage in the table below.

\begin{tabular}{|c|c|c|c|c|}
\hline Aspects & $\begin{array}{l}\text { Strongly } \\
\text { disagree }\end{array}$ & Disagree & Agree & $\begin{array}{l}\text { Strongly } \\
\text { Agree }\end{array}$ \\
\hline $\begin{array}{l}\text { 1. English blended learning improve my } \\
\text { grammar. }\end{array}$ & 0 & $28 \%$ & $60 \%$ & $12 \%$ \\
\hline $\begin{array}{l}\text { 2. I feel fun and enjoy in online and offline } \\
\text { learning. }\end{array}$ & 0 & $11 \%$ & $82 \%$ & $7 \%$ \\
\hline $\begin{array}{l}\text { 3. English blended learning improve my } \\
\text { language skills. }\end{array}$ & $5 \%$ & $2 \%$ & $91 \%$ & $2 \%$ \\
\hline 4. Triggering your autonomous learning & 0 & $26 \%$ & $53 \%$ & $21 \%$ \\
\hline $\begin{array}{l}\text { 5. I can be motivated in English blended } \\
\text { learning }\end{array}$ & 0 & $18 \%$ & $74 \%$ & $8 \%$ \\
\hline $\begin{array}{l}\text { 6. Blended Learning help me easier to } \\
\text { understand the material. }\end{array}$ & 0 & $10 \%$ & $63 \%$ & $27 \%$ \\
\hline $\begin{array}{l}\text { 7. I can manage the time for learning } \\
\text { through blended learning }\end{array}$ & 0 & $69 \%$ & $38 \%$ & $3 \%$ \\
\hline
\end{tabular}

According to the table, $72 \%$ students agree that English blended learning can improve the students' grammar achievement. The students also mentioned in the interview that they can practice and learn more about the grammar that they have been discussed in the offline meeting and practice in online meeting from the source provided by the teacher. Through this combining activity, there is a reinforcement activity for the students to understand about the grammar since they don't only get the explanation from the teacher in offline meeting but they can get more explanation from the media provided in online meeting such as in BBC channel or British Council Learning Website. Relating to the same investigation conducted by Isti'anah (2017) in investigating the impact of blended learning to the grammar students; achievement that for sure the students' grammar achievement can be increased through the blended learning implementation since online media can enrich the sources used for students to learn. In addition, the explanation that the students can get from YouTube and wiki as the effective educational tools in ELT can be fruitful supplement for students to understand about the material learned. Therefore, this statement in line with the data also obtained from questionnaire that $90 \%$ students gave their perspective that blended learning help them easier to understand the material in English learning. 
Otherwise, here are $38 \%$ students disagree that the implementation of English blended can improve their grammar achievement. The reason mention by the students in the interview that even though the materials learned have been explain by the teachers in offline meeting and added with the practice and explanation in online meeting, the students said that they still need some offline meeting out of the regular schedule such as consultation to make them more understand about the material. It can be denied that one of the lack in blended learning according to Chen \& Lu (2013) is the students have less opportunities to communicate naturally with the teacher which can only be obtained by the students in offline meeting.

In line with the teachers' perspective that the students as $Y$ Generation are more enjoy and fun in online learning than offline learning, according to the data obtained from questionnaire that $89 \%$ students agree that they feel fun and enjoy to learn through blended learning implementation. The students said that the online meeting in the blended learning implementation may give opportunities for students to learn independently and access unlimited sources that they need to understand the materials or even to improve their language skills. Wall \& Ahmed (2008); Garrison \& Kanuka (2004); Poon (2012) mention that online learning can create fun learning for students since there are a lot media can be accessed and used. It is in line with the investigation conducted by Engstrom and Jewtt (2005) about blended learning while they organized the students into group of four to six in order to make the wiki web pages manageable. The results showed that the participated students expressed satisfaction with their learning. The students indicated that they had the most positive experience.

Taking a look to the students' perspective in improving their language skills, 93\% students agree that since online meeting is implemented combining with offline meeting. The students can explore more media which can improve their language skills. The students also said in the interview that one of the media such as YouTube can help them to improve their listening and speaking skills since they like to watch English video and song from YouTube. It is in line with Johnson \& Swain (1997) that YouTube is one effective educational tool in Englishteaching and learning and also effective to help the teachers to find new ways to be used in order to improve students' listening and speaking ability. Moreover, supporting the statement from Banditvilai (2016) which mentioned that blended learning might improve the students' language skills, the students in the interview said that they can improve their language skills from their self-learning activity through online learning. The reason is because is because offline meeting has the limitation time for students to explore their language skills while in online meeting the students have more time to learn independently in order to improve their language skills.

The data obtained from questionnaire also mention that $74 \%$ students agree if blended learning can trigger the students autonomous in English learning since they can manage their learning time. Godwin \& Jones (2011) also agree that online learning such as computer assisted learning is able to improve students' autonomous learning especially in learning second or foreign language. The students can access the materials and exercise anytime they are ready to access while it can impact to the students to feel enjoy and motivate the students to learn English, as what can be seen from the data in the table above that $88 \%$ students feel that blended learning motivate them to learn English.

Otherwise, since in Indonesia there are around 14 subjects that the students in high school level should be learned, the students feel that they can't manage the time effectively for learning since blended learning is implemented during covid 19 pandemic. There are around $69 \%$ students in the questionnaire support this reason and said in the interview that since all subjects 
also implement bended learning and more exercise through online learning, they don't have enough time to learn one subject effectively. It can't be denied that since blended learning is implemented, the teachers also stated in the interview that most of the teachers give more students exercise and material comparing to before blended learning was implemented. Therefore, it can be one consideration to implement blended learning in Indonesia to be more planned well by the schools in order to avoid the over study load of the students and make the students can manage well the time to learn all subject during blended learning implementation. The Discussion should be an interpretation of the results rather than a repetition of the Results.

\section{CONCLUSION}

Of the seven aspects used as a parameter to determine teachers' perceptions of the implementation of blended learning, it is known that this learning model has advantages of about $90 \%$ and weaknesses $10 \%$. Meanwhile, from the students' point of view, the same learning model has advantages of around $77 \%$ and weaknesses of around $23 \%$. The results of this study could be concluded in general that the positive impact of blended learning according to the perceptions of teachers and students were : challenging for teachers in preparing the material and using the media; Blended Learning help the teachers to cover the lack exist in online and offline learning; helping students to English contextually; and making students improving their language skills.

Due to the results of the research, it's recommended that teachers must be wiser in choosing and providing subject matters in implementing this mixed method learning, and students are expected to be willing and able to take advantage of the current learning by being more active and participating in learning. Both parties must understand and realize all the advantages and disadvantages of blended learning in order to achieve the optimum results of implementing such learning.

\section{ACKNOWLEDGMENTS}

We, the writers, take this opportunity to express our first and foremost thanks to Allah SWT, who has given us the ability to complete this research. Furthermore, thanks are also conveyed to LPPM IKIP Siliwangi who has given us the confidence to conduct research as well as provide grants for its manufacture. Finally, we would like to express our gratitude to all those who have helped a lot both morally and materially so that this research can be completed. For the goodness of everything, we pray that all the good deeds given will get multiple rewards from Allah, SWT.Amen

\section{REFERENCES}

Adas, D., \& Bakir, A. (2013). Writing difficulties and new solutions: Blended learning as an approach to improve writing abilities. International Journal of Humanities and Social Science, 3(9), 254-266.

Akbarov, A., Gönen, K., \& Aydoğan, H. (2018). Students' attitudes toward blended learning in EFL context. Acta Didactica Napocensia, 11(1), 61-68. doi:10.24193/adn.11.1.5

Al-Haq, A. F. \& Al-Sobh, A. M. (2010). The effect of a web-based writing Instructional EFL program on enhancing the performance of Jordanian secondary students. The JALTCALL Journal 6 (3): 189-218.

Banditvilai, C (2016). Enhancing Students' Language Skills through Blended Learning. 
Research

Gate.

Available

At

https://www.researchgate.net/publication/306193961_Enhancing_students'_language_s kills_through_blended_learning.

Bielawska, Elzbieta Lesiak .(2012). The Impact of Blended Learning on Teaching English for Vocational Purposes. Published in researchgate.net/publication/291956635 (Online). DOI:10.14746/gl.2012.39.1.5

Bijeikiene, Rasinskiene, Zutkiene's (2011). Teachers' attitudes towards the use of blended learning in general English classroom. Studies About Languages, 18, 122-127.

Chansamrong, A., Tubsree, C., \& Kiratibodee, P. (2014). Effectiveness of cooperative and blended learning to assist Thai ESL students in learning grammar. HRD JOURNAL, 5(2), $105-115$.

Crookes, G. (2009). Values, Philosophies, and Beliefs in TESOL. Cambridge: Cambridge University Press.

Engstrom, M., \& Jewett, D. (2005). Collaborative learning the wiki way. Tech Trends: Linking Research and Practice to Improve Learning. 49 (6), 12-16.

Fakhir, Z. (2015). The impact of blended learning on the achievement of the English language students and their attitudes towards it. Master thesis, Middle East University, Amman, Jordan.

Garrison, D. R., \& Kanuka, H. (2004). Blended learning: Uncovering its transformative potential in higher education. The internet and higher education, 7(2), 95-105.

Ghazizadeh, T., \& Fatemipour, H. (2017). The effect of blended learning on EFL learners' reading proficiency. Journal of Language Teaching and Research, 8(3), 606-614. doi:10.17507/j1tr.0803.21.

Godwin-Jones, R. (2011). Autonomous language learning. Language Learning \& Technology, 15(3), 4-11

Grgurovic, M. (2011). Blended learning in an ESL class: A case study. Calico Journal, 29(1), 100.

Gultom, E. (2015). Linguistics and English Language Teaching. Proceedings of ISELT FBS Universitas Negeri Padang, 3, 125-129.

Hamied, F.A. (2012). Filsafat Ilmu. Bandung: SPs UPI.

Harris, L. R., \& Brown, G. T. (2010). Mixing interview and questionnaire methods: Practical problems in aligning data. Practical Assessment, Research, and Evaluation, 15(1), 1.

Isti'anah, A. (2017). The effect of blended learning to the students' achievement in grammar class. IJEE (Indonesian Journal of English Education), 4(1), 16-30. http://dx.doi.org/10.15408/ijee.v4i1.5697

Johnson, R. K., \& Swain, M. (1997). Immersion education: International perspectives. Cambridge: Cambridge University Press.

Lee, Chung Hyun (1997). The Use of Media Technology in Foreign Language Teaching and Learning at University Level: A Study of Teachers' Attitudes in Korea. University of Newcastle, England. Unpublished.

Liu, M. (2013). Blended Learning in a University EFL Writing Course: Description and Evaluation. Journal of Language Teaching \& Research, 4(2), 301-309. doi:10.4304/jltr.4.2.301-309.

Malik, R.S. \& Hamied, F.A. (2014). Research Methods: A Guide for First Time Researchers. Bandung: UPI Press.

Manan, N. A. A., Alias, A. A., \& Pandian, A. (2012). Utilizing a social networking website as an ESL pedagogical tool in a blended learning environment: An exploratory study. International Journal of Social Sciences \& Education, 2(1).

Pardede, Parlindungan. (2012). Blended Learning for ELT. Journal of English Teaching, 2(3). 
Poon, J. (2013). Blended learning: An institutional approach for enhancing students' learning experiences. Journal of online learning and teaching, 9(2), 271-288.

Rachman, Lukman Arif. (2015). Teaching and Learning English for Senior High School Level Based on Students and Teachers Perspective as Their Philosophical Foundation. Published in Seminar Nasional STKIP Siliwangi 2015.Cimahi

Riley, R. (2000). Intel® Teach to the Future Brings Together Microsoft and Other Industry Leaders in Half-Billion Dollar Commitment to Improve Student Learning. Selvarani, S \&Vadivio,S.K (2013). Technology to Support English Language Teaching and Learning..

Shen, Y. Q. (2004). The possibilities of teaching online English extensive reading in English major. Journal of Yulin Teachers College, 4, 108-110.

Shih, R. C. (2010). Blended learning using video-based blogs: Public speaking for English as a second language students. Australasian Journal of Educational Technology, 26(6).

Susikaran, R. S. A. (2013). Integrating ICT into Teaching \& Learning: A 21st Century Technology Tool for Continuing Education. International Journal of English and Education, 2(1), 289-295. 